\title{
Pengaruh Corporate social responsibility Disclosure, Beta \\ Dan Price to book value (PBV) Terhadap Earnings response coefficient (ERC) Pada Perusahaan Peraih ICSRA Tahun 2018
}

\author{
Safingil Anam, Aris Susetyo \\ Sekolah Tinggi Ilmu Ekonomi Putra Bangsa
}

Safingilanam290@gmail.com

\begin{abstract}
Abstrak
Penelitian ini bertujuan untuk mengetahui pengaruh corporate social responsibility, beta, dan price to book value secara parsial maupun simultan terhadap earnings response coeffecient perusahaan peraih ICSRA tahun 2018. Sumber data yang digunakan dalam penelitian ini adalah data skunder. Populasi yang digunakan dalam penelitian ini adalah perusahan yang mendapatkan penghargaan ISCRA tahun 2018 yang berjumlah 72 perusahaan. Teknik pengambilan sampel menggunakan metode purposive sampling yang menghasilkan jumlah sampel sebanyak 29 perusahaan dan 2 tahun sehingga membentuk data sebanyak 58 sampel. Teknik analisis yang digunakan adalah analisis regresi linear berganda dengan bantuan aplikasi SPSS 23. Hasil penelitian menunjukkan bahwa : 1) corporate social responsibility berpengaruh positif dan signifikan terhadap earnings response coeffecient, 2) beta berpengaruh positif dan signifikan terhadap earnings response coeffecient, 3) price to book value berpengaruh positif dan signifikan terhadap earnings response coeffecient, 4) corporate social responsibility, beta, price to book value berpengaruh signifikan terhadap earnings response coeffecient.
\end{abstract}

Kata Kunci : corporate social responsibility, beta, price to book value, earnings response coeffecient.

\begin{abstract}
The purpose of this research was to determine the effect of corporate social responsibility, beta, and price to book value partially and simultaneously on earnings response coefficients of ICSRA winning companies in 2018. The data sources used in this study were secondary data. The population used in this study was the company that received the ISCRA award in 2018 which amounted to 72 companies. The sampling technique used purposive sampling method which resulted in a total sample of 29 companies and 2 years so as to form data as many as 58 samples. The analysis technique used was multiple linear regression analysis with the help of SPSS 23 application. The results showed that: 1) corporate social responsibility has a positif and significant effect on earnings response coeffecient, 2) beta has a positif and significant effect on earnings response coeffecient, 3) price to book value has a positif and significant effect on earnings response coeffecient, 4) corporate social responsibility, beta, price to book value has a significant effect on earnings response coeffecient.
\end{abstract}

Keywords: corporate social responsibility, beta, price to book value, earnings response coefficients.

\section{PENDAHULUAN}

Informasi laporan keuangan perusahaan dianggap paling relevan dalam pengambilan keputusan investasi. Laporan keuangan adalah laporan yang diterbitkan oleh perusahaan yang digunakan sebagai sarana untuk mengkomunikasikan informasi keuangan perusahaan kepada pihak eksternal seperti investor dan kreditor. Salah satu unsur dalam laporan keuangan yang paling banyak mendapat perhatian adalah laporan laba rugi perusahaan. Laba dapat dijadikan sebagai ukuran kinerja perusahaan, sehingga informasi laba menjadi referensi bagi investor untuk menanamkan investasinya pada perusahaan tersebut karena baik laba/rugi akan mempengaruhi return saham.

Reaksi pasar yang berbeda-beda terhadap informasi laba dapat disebabkan oleh berbagai hal. Dalam penelitian ini akan diuji beberapa faktor yang diduga mempengaruhi ERC, diantaranya yaitu corporate social responsibility (CSR) disclosure, dimana CSR merupakan konsep akuntansi baru yang muncul setelah adanya banyak kritik terhadap akuntansi konvensional yang dianggap tidak dapat mengakomodir kepentingan stakeholder. Stakeholder adalah orang atau kelompok yang memiliki kepentingan terhadap aktivitas perusahaan baik secara langsung atau tidak langsung.

Kesadaran stakeholder akan pentingnya pembangunan berkelanjutan yang dilakukan oleh perusahaan mendorong perusahaan untuk mengungkapkan kegiatan atau praktikptaktik Corporate social responsibility yang dilakukan. Semakin kuatnya tekanan dari stakeholder dalam hal pengungkapan Corporate social responsibility yang dilakukan oleh perusahaan menyebabkan perlunya memasukkan unsur sosial dalam pertanggungjawaban perusahaan kedalam laporan tahunan (annual report).

Dalam Undang-Undang No. 40 Tahun 2007 tentang Perseroan Terbatas, pada Pasal 66 ayat (2) bagian c dan pasal 74. Inti dari kedua pasal tersebut adalah mengatur tentang kewajiban perusahaan disamping menyampaikan laporan keuangan juga melaporkan pelaksanaan tanggung jawab sosial dan lingkungan didalam laporan tahunan. 


\section{Pengaruh Corporate social responsibility Disclosure, Beta Dan Price to book value (PBV) Terhadap Earnings response coefficient (ERC) Pada Perusahaan Peraih ICSRA Tahun 2018}

Pentingnya penerapan program CSR sebagai bagian dari strategi bisnis, semakin disadari oleh perusahaan.

Majalah Indonesia Asia Institute Economic Review Ideku Group menyelenggarakan ajang Indonesia Corporate Sosial Responsibility Award (ICSRA) dalam rangka memberikan apresiasi kepada perusahaan yang menjalankan program CSR secara baik. Indonesia Corporate Sosial Responsibility Award (ICSRA) tahun 2018 dilaksanakan pada hari Jum'at, 23 Februari 2018 di Hotel Crown Plaza Jakarta dengan menempatkan 72 perusahaan terbaik terkait penerapan CSR. Aspek yang dinilai berdasarkan publikasi kegiatan CSR (20\%), keterlibatan stakeholder 20\%, cakupan kegiatan CSR $40 \%$ meliputi kesehatan, lingkungan, pendidikan dan sosial serta dampak jangka panjang CSR bagi masyarakat sasaran $20 \%$.

Riset terbaru menyatakan perusahaan di Indonesia memiliki kualitas tanggung jawab sosial atau corporate social responsibility (CSR) yang rendah. Riset Centre for Governance, Institutions, and Organizations National University of Singapore (NUS) Business School memaparkan rendahnya pemahaman perusahaan terhadap praktik CSR, menyebabkan rendahnya kualitas pengoperasian agenda tersebut. Riset ini melakukan studi terhadap 100 perusahaan di empat negara yakni Indonesia, Malaysia, Singapura dan Thailand.Tabel I-1

\section{Hasil Riset CSR}

\begin{tabular}{lll}
\hline No & Negara & Nilai \\
\hline 1 & Thailand & 56,8 \\
2 & Singapura & 48,8 \\
3 & Indonesia & 48,4 \\
4 & Malaysia & 47,7 \\
\hline
\end{tabular}

Sumber : CNN Indonesia

Penelitian yang dilakukan wulandari dan wirajaya (2014) membuktikan bahwa pengungkapan program corporate social responsibility tidak berpengaruh terhadap earnings response coefficient. Hal yang sama diungkapkan oleh silalahi (2014) yang juga menemukan bahwa corporate social responsibility tidak berpengaruh signifikan terhadap earnings response coefficient kerena investor masih memberikan respon lebih terhadap informasi laba dibandingkan laporan pertanggung jawaban sosial dalam pengambilan keputusan investasi. Hasil berbeda datang dari penelitian yang dilakukan oleh Fariba (2013) yang mengatakan bahwa corporate social responsibility berpengaruh terhadap earnings response coefficient meskipun tingkat reaksi investor terhadap pengungkapan corporate social responsibility lemah yaitu $13,3 \%$.

Adapun faktor lain yang diduga dapat mempengaruhi earnings response coefficient yaitu price to book value dan beta. Price to book value menggambarkan seberapa besar pasar menghargai nilai buku saham suatu perusahaan, sedangkan beta menurut Jogiyanto (2010:357) merupakan suatu pengukur volatilitas return sekuritas terhadap return pasar. Penelitian yang dilakukan oleh palupi (2006) dalam silalahi (2014) mengenai analisis faktor-faktor yang mempengaruhi koefisien respon laba, bukti empiris pada Bursa Efek Jakarta menyatakan secara signifikan bahwa koefisien respon laba dipengaruhi oleh risiko sistematik. Semakin besar risiko sistematik, semakin besar koefisien respon laba.

Sejalan dengan penelitian sebelumnya yang dilakukan oleh Indra, dkk (2011) menemukan bahwa beta memiliki pengaruh positif terhadap koefisien respon laba. Namun pada penelitian imroatussolihah (2013) menghasilkan bahwa beta berpengaruh negatif terhadap earnings response coefficient, yang berarti semakin tinggi risiko suatu perusahaan maka semakin rendah reaksi investor terhadap laba kejutan maka earnings response coefficient semakin rendah. Begitupun penelitian yang dilakukan oleh silalahi (2014) yang mengatakan bahwa beta tidak berpengaruh terhadap earnings response coefficient karena rendahnya nilai variable beta, sedangkan terdapat pengaruh yang signifikan antara price to book value terhadap earnings response coefficient karena perusahaan yang terus menerus tumbuh memiliki kemudahan dalam menarik modal yang merupakan sumber pertumbuhan. Akan tetapi, penelitian yang dilakukan oleh Imroatussolihah (2013) memperoleh hasil bahwa price to book value tidak memiliki pengaruh terhadap earnings response coefficient (ERC).

Fokus dari penelitian ini adalah untuk menguji kembali pengaruh corporate social responsibility disclosure, beta dan price to book value terhadap earnings response coefficient. Objek dari penelitian ini adalah perusahaan peraih ICSRA tahun 2018. Perusahaan ini dipilih karena perusahaan yang terdaftar sebagai perusahaan peraih ICSRA tahun 2018 adalah perusahaan-perusahaan terpilih yang mendapatkan apresiasi penghargaan tertinggi dibidang CSR. Alasan lain karena perusahaan peserta ICSRA diikuti oleh perusahaan BUMN, BUMD, BankPersero, BPD, BPR-Syariah, Properti, Konstruksi, Telekomunikasi, Minuman, Farmasi, Tol, Swasta sehingga dapat menjadi perwakilan perusahaan-perusahaan yang ada di Indonesia. Berdasarkan fenomena di atas, maka penulis tertarik melakukan penelitian dengan judul "PENGARUH CORPORATE SOCIAL RESPONSIBILITY DISCLOSURE, BETA DAN PRICE TO BOOK VALUE (PBV) TERHADAP EARNINGS RESPONSE COEFFICIENT (ERC) PADA PERUSAHAAN PERAIH ICSRA TAHUN 2018". 


\section{Pengaruh Corporate social responsibility Disclosure, Beta \\ Dan Price to book value (PBV) Terhadap Earnings response coefficient (ERC) \\ Pada Perusahaan Peraih ICSRA Tahun 2018}

\section{KAJIAN PUSTAKA}

\section{Corporate social responsibility (CSR)}

Menurut The World Business Council for Sustainable Development (WBCSD), Corporate Social Responsibility atau tanggung jawab sosial perusahaan didefinisikan sebagai komitmen bisnis untuk memberikan kontribusi bagi pembangunan ekonomi berkelanjutan, melalui kerja sama dengan para karyawan serta perwakilan mereka, keluarga mereka, komunitas setempat maupun masyarakat umum untuk meningkatkan kualitas kehidupan dengan cara yang bermanfaat baik bagi bisnis sendiri maupun untuk pembangunan.

\section{Beta}

Menurut Jogiyanto (2014:405) beta merupakan pengukur volatilitas return sekuritas terhadap return pasar.

Volatilitas dapat didefinisikan sebagai fluktuasi return sekuritas dalam periode tertentu. Contoh risiko sitematik (tidak dapat dihindari) peningkatan suku bunga (interest rate risk), kenaikan inflasi (purchasing power/ inflationari risk) dan volatilitas pasar yang tinggi (market risk).

Risiko non sistematik contohnya likuiditas, risisko kebangkrutan, risisko tuntutan hukum (operational risk).

\section{Price to book value}

Menurut Darmadji dan Fakhruddin (2011:157), price to book value menggambarkan seberapa besar menghargai nilai buku saham suatu perusahaan.

Makin tinggi rasio ini berarti pasar percaya akan prospek perusahaan tersebut. Price to book value adalah rasio yang menunjukkan apakah harga saham diperdagangkan di bawah (undervalued) atau di atas (overvalued) nilai buku saham tersebut. Price to book value digunakan untuk memproksi growth opportunities. Growth opportunities adalah pertumbuhan perusahaan di masa yang akan datang.

\section{MODEL EMPIRIS}

1. Pengaruh Corporate social responsibility Disclosure terhadap Earnings response coefficient

Elkington (1997) dalam Wibisono (2007) menyebut sistem pelaporan yang menyertakan informasi corporate social responsibility sebagai triple bottom line reporting, yaitu pelaporan yang menyajikan informasi tentang kinerja ekonomi (profit), lingkungan, dan sosial dari suatu entitas korporasi. Program corporate social responsibility diharapkan dapat membantu perusahaan untuk dapat diterima oleh masyarakat, baik aktivitas maupun kinerjanya dan juga untuk meningkatkan keuangan dalam jangka panjang, seperti meningkatkan laba. Ketika terjadi pengumuman laba, maka akan terjadi reaksi pasar (contohnya dari investor) yang dapat diukur dengan earnings response coefficient.

\section{Pengaruh Beta terhadap Earnings response coefficient}

Menurut Jogiyanto (2014:405) beta merupakan pengukur volatilitas return sekuritas terhadap return pasar. Volatilitas dapat didefinisikan sebagai fluktuasi return sekuritas dalam periode tertentu. Ukuran risiko yang relevan dari sekuritas adalah beta. Semakin tinggi beta maka permintaan terhadap saham perusahaan itu semakin menurun, sehingga permintaan yang rendah mengimplikasikan peningkatan yang rendah dalam harga pasar dan return saham yang menjadikan earnins response coefficient rendah.

\section{Pengaruh Price to book value terhadap Earnings response coefficient}

Price to book value menggambarkan seberapa besar pasar menghargai nilai buku saham suatu perusahaan. Semakin tinggi rasio maka pasar semakin percaya akan prospek perusahaan tersebut (Darmadji dan Fakhruddin, 2011:157). Ketika profitabilitas suatu perusahaan meningkat, maka hal ini juga dapat meningkatkan asset perusahaan. Hal ini menunjukkan kepada pasar bahwa perusahaan mampu untuk bertumbuh dan dapat meningkatkan rasio price to book value. Peningkatan laba yang menunjukkan peluang pertumbuhan dapat meningkatkan earnings response coefficient.

\section{KERANGKA PEMIKIRAN}

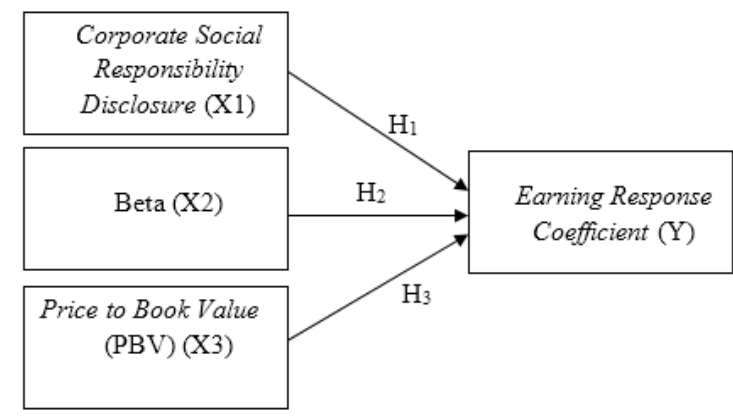

\section{HIPOTESIS}

$\mathrm{H}_{1}$ : Terdapat pengaruh CSR terhadap ERC pada perusahaan peraih penghargaan ICSRA Tahun 2018.

$\mathrm{H}_{2}$ : Terdapat pengaruh Beta terhadap ERC pada perusahaan peraih penghargaan ICSRA Tahun 2018.

$\mathrm{H}_{3}$ : Terdapat pengaruh PBV terhadap ERC pada perusahaan peraih penghargaan ICSRA Tahun 2018. 


\section{METODOLOGI PENELITIAN}

\section{Obyek penelitan}

Obyek dalam penelitian ini adalah Corporate social responsibility (CSR), Beta dan Price to book value (PBV) dan Earning Response Coeffisien pada perusahaan yang mendapatkan penghargaan ICSRA tahun 2018.

\section{Subyek Penelitian}

Subyek dalam penelitian ini adalah perusahaan peraih penghargaan ICSRA tahun 2018 berjumlah 72 perusahaan.

\section{Populasi}

Populasi adalah wilayah generalisasi yang terdiri atas: obyek/ subyek yang mempunyai kualitas dan karakteristik tertentu yang ditetapkan oleh peneliti untuk dipelajari dan kemudian ditarik kesimpulannya (Sugiyono, 2010: 115). Populasi yang di gunakan dalam penelitian ini adalah perusahaan yang mendapatkan penghargaan ICSRA Tahun 2018 sebanyak 72 perusahaan.

\section{Sampel}

Sampel adalah bagian dari jumlah dan karakteristik yang dimiliki oleh populasi (Sugiyono, 2010: 116). Teknik pengambilan sampel yang digunakan adalah purposive sampling. Menurut Sugiyono (2010: 122) purposive sampling adalah teknik penentuan sampel dengan pertimbangan tertentu. Pertimbangan yang digunakan untuk penentuan sampel dalam penelitian ini adalah sebagai berikut:

a. Perusahaan yang mendapat penghargaan ICSRA tahun 2018

b. Tidak Listing di Bursa Efek Indonesia (BEI) tahun 2016-2017

Berdasarkan hasil laporan yang bersumber dari Majalah Indonesia Asia Institute Economic Review Ideku Group yang dipublikasikan 24 februari 2018 jumlah perusahaan yang mendapatkan penghargaan ICSRA tahun 2018 adalah 72 perusahaan. Perusahaan tersebut kemudian diseleksi dengan kriteria yang sudah ditentukan.

\begin{tabular}{clc}
\hline No & \multicolumn{1}{c}{ Kriteria Sampel } & Jumlah \\
\hline $\mathbf{1}$ & $\begin{array}{l}\text { Perusahaan yang mendapat } \\
\text { penghargaan ICSRA tahun } 2018\end{array}$ & $\mathbf{7 2}$ \\
$\mathbf{2}$ & $\begin{array}{l}\text { Tidak listing di BEI tahun 2016- } \\
2017\end{array}$ & $\mathbf{( 4 3 )}$ \\
\hline & Sampel & $\mathbf{2 9}$ \\
\hline & Total Pengamatan (29X2) & $\mathbf{5 8}$ \\
\hline
\end{tabular}

\section{HASIL DAN PEMBAHASAN UJI STATISTIK}

\begin{tabular}{lrrrrr}
\hline & N & \multicolumn{1}{c}{ Min } & \multicolumn{1}{c}{ Max } & \multicolumn{1}{c}{ Mean } & \multicolumn{1}{c}{ Std. Deviation } \\
\hline CSR & 58 & .64 & .95 & .8297 & .07172 \\
Beta & 58 & -6.11 & 54.13 & 1.9319 & 7.22835 \\
PBV & 58 & .27 & 62.93 & 4.5845 & 11.71553 \\
ERC & 58 & -45.27 & 28.73 & .9845 & 11.64831 \\
Valid N & & & & & \\
(listwise & 58 & & & & \\
) & & & & & \\
\hline
\end{tabular}

\section{UJI NORMALITAS}

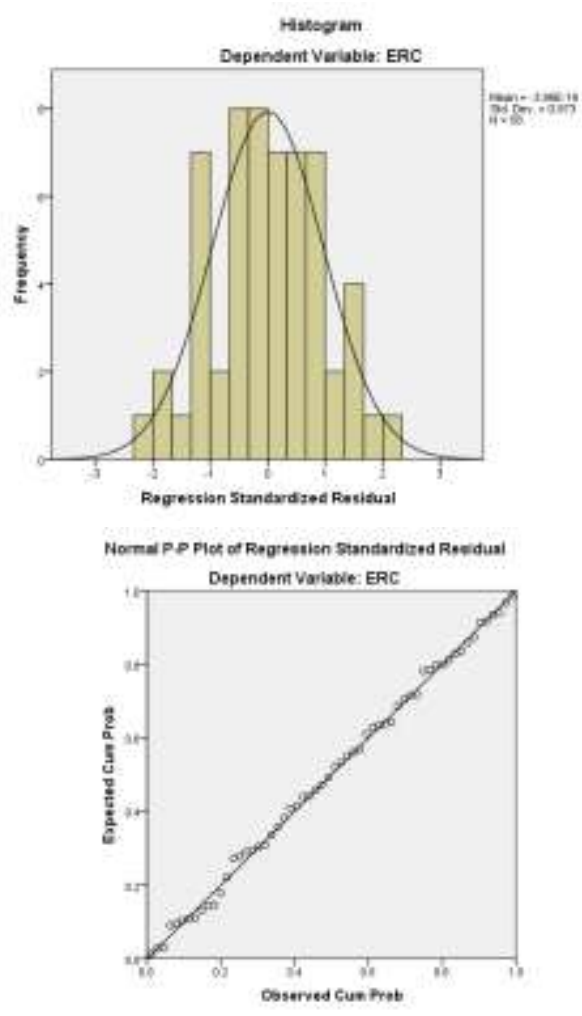

\section{UJI MULTIKOLINEARITAS}

Coefficients $^{\mathrm{a}}$

\begin{tabular}{|c|c|c|c|c|c|}
\hline \multirow[b]{2}{*}{ Model } & \multicolumn{2}{|c|}{$\begin{array}{l}\text { Unstandardized } \\
\text { Coefficients }\end{array}$} & $\begin{array}{l}\text { Standardized } \\
\text { Coefficients }\end{array}$ & \multicolumn{2}{|c|}{$\begin{array}{l}\text { Collinearity } \\
\text { Statistics }\end{array}$} \\
\hline & B & $\begin{array}{l}\text { Std. } \\
\text { Error }\end{array}$ & Beta & $\begin{array}{l}\text { Toler } \\
\text { ance }\end{array}$ & VIF \\
\hline (Constant) & 2.829 & 1.210 & & & \\
\hline $\operatorname{csr}$ & 9.056 & 2.785 & .378 & .978 & 1.022 \\
\hline beta & .415 & .204 & .236 & .980 & 1.021 \\
\hline pbv & .480 & .232 & .238 & .999 & 1.001 \\
\hline
\end{tabular}

a. Dependent Variable: erc

\section{UJI AUTOKORELASI}

\begin{tabular}{llllll}
\multicolumn{7}{c}{ Model Summary $^{\mathbf{b}}$} & & & \\
\hline & & & Adjusted R & Std. Error of & Durbin- \\
Model & R & R Square & Square & the Estimate & Watson \\
\hline 1 & $.536^{\mathrm{a}}$ & .288 & .248 & 3.66270 & 2.266 \\
\hline
\end{tabular}


a. Predictors: (Constant), pbv, beta, csr

b. Dependent Variable: erc

\section{UJI HETEROKEDASTISITAS}

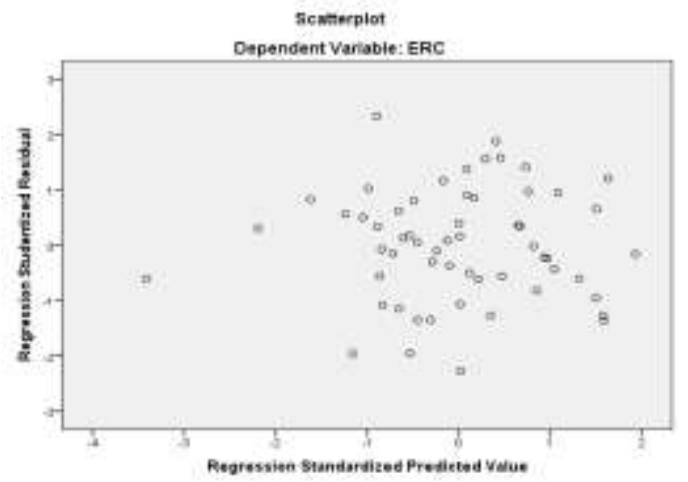

UJI HIPOTESIS

A. Uji Parsial

Coefficients $^{\mathrm{a}}$

\begin{tabular}{|c|c|c|c|c|c|}
\hline \multirow[b]{2}{*}{ Model } & \multicolumn{2}{|c|}{$\begin{array}{l}\text { Unstandardized } \\
\text { Coefficients }\end{array}$} & \multirow{2}{*}{$\begin{array}{l}\text { Standardized } \\
\text { Coefficients } \\
\text { Beta }\end{array}$} & \multirow{3}{*}{$\begin{array}{l}\mathrm{t} \\
2.337\end{array}$} & \multirow{3}{*}{$\begin{array}{l}\text { Sig. } \\
.023\end{array}$} \\
\hline & $\mathrm{B}$ & Std. Error & & & \\
\hline 1 (Constant) & 2.829 & 1.210 & & & \\
\hline $\operatorname{csr}$ & 9.056 & 2.785 & .378 & 3.251 & .002 \\
\hline beta & .415 & .204 & .236 & 2.032 & .047 \\
\hline $\mathrm{pbv}$ & .480 & .232 & .238 & 2.074 & .043 \\
\hline
\end{tabular}

1. CSR Disclosure (X1) terhadap ERC (Y)

Berdasarkan pada tabel IV-7 dapat dilihat bahwa nilai thitung sebesar 3.251 lebih besar dari ttabel 2.00404 (3.251 > 2.00404). Dilihat dari nilai signifikan CSR Disclosure memiliki nilai signifikan sebesar 0.002 $<0.05$, maka dapat disimpulkan bahwa CSR (X1) memiliki pengaruh positif dan signifikan terhadap ERC (Y).

2. Beta (X2) terhadap ERC (Y)

Berdasarkan pada tabel IV-7 dapat dilihat bahwa nilai thitung sebesar 2.032 lebih besar dari ttabel $2.00404(2.032>2.00404)$. Dilihat dari nilai signifikan Beta memiliki nilai signifikan sebesar $0.047<0.05$, maka dapat disimpulkan bahwa Beta (X2) memiliki pengaruh positif dan signifikan terhadap ERC (Y).

3. PBV (X3) terhadap ERC (Y)

Berdasarkan pada tabel IV-7 dapat dilihat bahwa nilai thitung sebesar 2.074 lebih besar dari ttabel 2.00404 ( $2.074>2.00404)$. Dilihat dari nilai signifikan PBV memiliki nilai signifikan sebesar $0.043<0.05$, maka dapat disimpulkan bahwa PBV (X3) memiliki pengaruh positif dan signifikan terhadap ERC (Y).

Kriteria penerimaan hipotesis:

a. jika t-hitung > t-tabel, maka hipotesis yang diajukan diterima.

b. jika t-hitung $<\mathrm{t}$-tabel, maka hipotesis yang diajukan ditolak.
Corporate Sosial Responsibility $(\mathrm{CSR})=3.251>2.00404$ maka hipotesis diterima

Beta $=2.032>2.00404$ maka hipotesis diterima Price to book value $(\mathrm{PBV})=2.074>2.00404$ maka hipotesis diterima

Maka kesimpulannya: CSR Disclosure, Beta, dan PBV secara parsial mempengaruhi ERC.

\section{B. Uji Simultan}

\begin{tabular}{|c|c|c|c|c|c|c|}
\hline \multicolumn{7}{|c|}{ ANOVA $^{\mathrm{a}}$} \\
\hline \multirow{2}{*}{\multicolumn{2}{|c|}{ Model }} & Sum of & & Mean & & \\
\hline & & Squares & df & Square & $\mathrm{F}$ & Sig. \\
\hline \multirow[t]{3}{*}{1} & Regression & 292.402 & 3 & 97.467 & 7.265 & $.000^{\mathrm{b}}$ \\
\hline & Residual & 724.431 & 54 & 13.415 & & \\
\hline & Total & 1016.833 & 57 & & & \\
\hline
\end{tabular}

a. Dependent Variable: erc

b. Predictors: (Constant), pbv, beta, csr

Sumber : data diolah SPSS 23, 2019

Berdasarkan hasil uji diatas, diperoleh nilai fhitung sebesar $7.265>$ ftabel sebesar 3.16 dengan tingkat signifikan 0,000b $<0,05$ maka dapat disimpulkan bahwa CSR Disclosure, Beta dan PBV berpengaruh secara simultan terhadap ERC pada Perusahaan peraih ICSRA Tahun 2018.

\section{KOEFESIEN DETERMINASI}

Model Summary

\begin{tabular}{lrrrrr}
\hline & & & Adjusted & \multicolumn{2}{l}{$\begin{array}{l}\text { Std. Error of the } \\
\text { Model }\end{array}$} \\
\hline & R & R Square & R Square & \multicolumn{2}{l}{ Estimate } \\
\hline 1 & $.536^{\mathrm{a}}$ & .288 & .248 & 3.66270 \\
\hline
\end{tabular}

a. Predictors: (Constant), pbv, beta, csr

b. Dependent Variable: erc

Sumber : data diolah SPSS 23, 2019

Berdasarkan Tabel IV-9 dapat dilihat bahwa nilai Adjusted R Square sebesar 0.174, hal ini berarti variabel CSR Disclosure, Beta dan PBV memiliki pengaruh terhadap ERC sebesar 24.8\%. Sedangkan sisa (100\% $24.8 \%$ ) sebesar $75.2 \%$ dipengaruhi oleh variabel yang lain di luar model penelitian.

\section{IMPLIKASI MANAJERIAL}

1. Pengaruh Corporate Social Responsibility (CSR) Disclosure terhadap Earnings response coefficient (ERC)

Pengujian hipotesis pertama bertujuan untuk mengetahui pengaruh Corporate Social Responsibility (CSR) Disclosure terhadap Earnings response 


\section{Pengaruh Corporate social responsibility Disclosure, Beta \\ Dan Price to book value (PBV) Terhadap Earnings response coefficient (ERC) \\ Pada Perusahaan Peraih ICSRA Tahun 2018}

coefficient (ERC). Hasil penelitian ini menunjukkan CSR Disclosure memiliki pengaruh yang signifikan terhadap ERC. Dengan hasil uji t, thitung sebesar 3.251 lebih besar dari ttabel 2.00404 (3.251 > 2.00404) dan nilai signifikan CSR Disclosure sebesar $0.002<0.05$, maka dapat disimpulkan bahwa CSR Disclosure (X1) memiliki pengaruh positif signifikan terhadap ERC (Y).

Hasil analisis dalam penelitian ini menunjukkan pengungkapan Corporate social responsibility (CSR) mempengaruhi Earnings response coefficient (ERC). Artinya bahwa tingginya tingkat pengungkapan Corporate social responsibility (CSR) berpengaruh pada tingginya tingkat Earnings response coefficient (ERC). Dengan demikian, perusahaan yang memiliki kinerja yang baik melalui pengungkapan CSR akan mendapat respon aktif dari investor melalui peningkatan harga saham. Hal tersebut berdampak pada laba yang tinggi sehingga mempengaruhi peningkatan ERC. Respon aktif dari investor juga dapat terjadi karena pengungkapan CSR telah ditetapkan sebagai kewajiban bagi perusahaan untuk melakukan pengungkapan CSR dalam laporan tahunan.

Hasil penelitian ini sejalan dengan penelitian yang dilakukan oleh Fariba (2013) yang menyatakan bahwa pengungkapan CSR berpengaruh terhadap ERC, berarti investor mengapresiasi informasi CSR yang diungkapkan dalam laporan tahunan perusahaan. Berbeda dengan penelitian yang dilakukan oleh Silalahi (2014), yang menunjukkan bahwa tidak terdapat pengaruh yang signifikan antara pengungkapan CSR dan ERC. Hal ini menunjukkan bahwa investor kemungkinan masih memberikan respon yang lebih besar terhadap informasi laba daripada pengungkapan CSR dalam pengambilan keputusan berinvestasi.

\section{Pengaruh Beta terhadap Earnings response coefficient (ERC)}

Pengujian hipotesis kedua bertujuan untuk mengetahui pengaruh Beta terhadap Earnings response coefficient (ERC). Hasil penelitian ini menunjukkan bahwa Beta memiliki pengaruh yang signifikan terhadap ERC. Dengan nilai thitung sebesar 2.032 lebih besar dari ttabel 2.00404 (2.032 > 2.00404). Dilihat dari nilai signifikan ukuran perusahaan memiliki nilai signifikan sebesar $0.047<0.05$, maka dapat disimpulkan bahwa Beta (X2) memiliki pengaruh positif dan signifikan terhadap ERC (Y).

Saham dengan beta satu merupakan saham yang bergerak searah pergerakan pasar. Kemudian saham dengan beta kurang dari satu merupakan saham yang bergerak lebih lambat dari pergerakan pasar, sementara yang memiliki beta lebih dari satu menggambarkan harga saham bergerak lebih fluktuaktif dibanding pasar.
Beta sering disebut koefisien beta yang merupakan ukuran angka koefisien yang menggambarkan sensitivitas atau kecenderungan respons suatu saham terhadap pasar. Beta suatu saham yang tinggi menunjukkan tingkat risiko yang tinggi pada saham tersebut, namun tingkat risiko yang tinggi ini biasanya memberikan tingkat pengembalian investasi yang tinggi juga. Tingginya koefisien beta menunjukan tingginya pengembalian suatu investasi sehingga akan meningkatkan respon dari investor dan akan mempengaruhi ERC.

Sejalan dengan penelitian palupi (2006) dan indra, dkk (2011) menyatakan bahwa beta berpengaruh positif terhadap ERC, sehingga semakin tinngi beta semakin tinggi pula ERC. Berbeda dengan penelitian yang dilakukan oleh imroatussolihah (2013) yang menyatakan beta berpengaruh negatif terhadap ERC sedangkan penelitian yang dilakukan oleh silalahi 2014 menyatakan bahwa beta tidak berpengaruh terhadap ERC.

3. Pengaruh Price to book value (PBV) terhadap Earnings response coefficient (ERC)

Pengujian hipotesis ketiga bertujuan untuk mengetahui pengaruh PBV terhadap Earnings response coefficient (ERC). Hasil penelitian ini menunjukkan PBV memiliki pengaruh yang signifikan terhadap ERC, dengan nilai thitung sebesar 2.074 lebih besar dari ttabel $2.00404(2.074>2.00404)$. Dilihat dari nilai signifikan PBV memiliki nilai signifikan sebesar 0.043 $<0.05$, maka dapat disimpulkan bahwa PBV (X3) memiliki pengaruh positif dan signifikan terhadap ERC (Y).

Price to book value (PBV) yang baik adalah yang bernilai lebih dari 1 atau nilai pasar lebih tinggi daripada nilai buku saham, artinya ketika nilai PBV tinggi maka akan berdampak pada tingginya nilai ERC. Price to book value (PBV) yang semakin besar akan menunjukkan harga saham dari perusahaan tersebut semakin meningkat. Semakin tinggi nilai PBV semakin tinggi pula penilaian investor terhadap perusahaan yang bersangkutan, sehingga semakin tingga pula nilai ERC.

Penelitian ini sejalan dengan hasil penelitian yang dilakukan oleh silalahi (2014) yang juga menemukan bahwa kesempatan bertumbuh memiliki pengaruh positif terhadap ERC. Akan tetapi, penelitian yang dilakukan oleh Imroatussolihah (2013) memperoleh hasil bahwa kesempatan bertumbuh tidak memiliki pengaruh terhadap ERC.

\section{PENUTUP \\ Simpulan}

Berdasarkan analisis regresi linear berganda corporate social responsibility disclosure, beta, price to book value 


\section{Pengaruh Corporate social responsibility Disclosure, Beta \\ Dan Price to book value (PBV) Terhadap Earnings response coefficient (ERC) \\ Pada Perusahaan Peraih ICSRA Tahun 2018}

terhadap earning response coeffecient diperoleh kesimpulan sebagai berikut.

1. Corporate social responsibility (CSR) memiliki pengaruh positif dan signifikan terhadap Earnings response coefficient (ERC), hal ini ditunjukkan dari koefisien regresi sebesar 9.052 dan nilai thitung sebesar 3.251 lebih besar dari ttabel 2.00404 (3.251 > 2.00404) dengan signifikan sebesar $0.002<0.05$ sehingga H1 diterima.

2. Beta memiliki pengaruh positif dan signifikan terhadap Earnings response coefficient (ERC), hal ini ditunjukkan dari koefisien regresi sebesar 0.415 dan nilai thitung sebesar 2.032 lebih besar dari ttabel $2.00404(2.032>2.00404)$ dengan signifikan sebesar $0.047<0.05$ sehingga $\mathrm{H} 2$ diterima.

3. Price to book value (PBV) memiliki pengaruh positif dan signifikan terhadap Earnings response coefficient (ERC), hal ini ditunjukkan dari koefisien regresi sebesar 0.480 dan nilai thitung sebesar 2.074 lebih besar dari ttabel 2.00404 (2.074 > 2.00404) dengan signifikan sebesar $0.043<0.05$ sehingga H3 diterima.

4. CSR Disclosure, Beta dan PBV secara simultan berpengaruh terhadap earnings response coefficient, hal ini ditunjukkan denagn nilai nilai fhitung sebesar $7.265>$ ftabel sebesar 3.16 dengan tingkat signifikan $0,000 \mathrm{~b}<0,05$.

5. Pada penelitian ini dihasilkan model penelitian:

$\mathrm{Y}=2.829+9.056(\mathrm{X} 1)+0.415(\mathrm{X} 2)+0.480(\mathrm{X} 3)+\mathrm{e}$ Besarnya pengaruh variasi variabel independen yaitu csr disclosure, beta dan pbv terhadap earnings response coefficient di tunjukkan dari nilai koeffisien determinasi (adjusted R-squared) sebesar $24.8 \%$ sedangkan sisanya $75,2 \%$ dijelaskan oleh variabel lain diluar model penelitian.

\section{Saran}

Berdasarkan hasil penelitian, berikut ini saran yang diberikan penulis.

1. Bagi Perusahaan

Perusahaan disarankan untuk lebih memperhatikan faktor-faktor yang mempengaruhi ERC yang mengukur kualitas laba perusahaan agar mendapat respon baik dari investor, diantaranya lebih meningkatkan komitmen dalam pelaksanaan CSR secara berkelanjutan sehingga pengungkapannya juga akan semakin besar. Dengan demikian investor akan semakin mempertimbangkan informasi yang terkandung dalam pengungkapan tersebut. Karena sangat pentingnya informasi laba bagi investor dalam proses pengambilan keputusan, maka sebaiknya investor lebih cermat lagi dalam menganalisa setiap laporan tahunan agar informasi yang didapat benarbenar menggambarkan perusahaan baik sekarang atau prospek kedepannya. Selain meningkatkan pengungkapan CSR, perusahaan juga harus memperhatikan nilai koefisien beta dan price to book value untuk meningkatkan kualitas laba perusahaan.

2. Bagi Investor

Investor disarankan lebih mempertimbangkan untuk memperhatikan pengungkapan CSR, PBV dan Beta dalam menganalisa kualitas laba perusahan agar informasi yang didapat menggambarkan keadaan perusahaan baik sekarang maupun prospek kedepanya.

3. Bagi Peneliti Selanjutnya

Untuk penelitian selanjutnya, diharapkan dapat menambah variabel independen lain yang bisa mempengaruhi Earnings response coefficient (ERC). Penelitian ini menggunakan data populasi perusahaan peraih ICSRA di Bursa Efek Indonesia, dengan menggunakan metode purposive sampling diperoleh sampel sebanyak 29 perusahaan. Mengingat jumlah sampel yang sedikit, diharapkan untuk penelitian selanjutnya dapat menambahkan sampel penelitian lain atau menggunakan data populasi seluruh perusahaan yang terdaftar di BEI, karena dengan menambah jumlah perusahaan diperkirakan bisa meningkatkan hasil yang lebih baik

\section{DAFTAR PUSTAKA}

Brigham, Eugene F dan Houston. 2006. Fundamental of FinancialManagement: Dasar-Dasar Manajemen Keuangan. Edisi 10. Jakarta: Salemba Empat.

Bursa Efek Indonesia.2017. "Laporan tahunan perusahaan". www.finance.yahoo.com. Diakses pada hari kamis, 20 Desember 2018 jam 19.00 WIB

Bursa Efek Indonesia.2017. "Laporan tahunan perusahaan".www.idx.co.id. Diakses pada hari rabu, 19 Desember 2018 jam 20.00 WIB

Cho. J.Y., \& Jung, K. (1991). Earnings response coefficient: A Sythesis of Theory and Empirical Evidence. Journal of Accounting Literature. Vol.10:85-116.

Darmadji \& Fakhruddin. 2011.Pasar Modal di Indonesia. Edisi 3.Jakarta: Salemba Empat.

Dessthania, Riva. (2016). "Riset Temukan Kualitas CSR Perusahaan Indonesia Rendah" dari https://www.cnnindonesia.com/nasional/2016072107 4144-20-146030/riset-temukan-kualitas-csrperusahaan-indonesia-rendah. Diakses pada hari rabu, 5 September 2018 jam 17.00 WIB 


\section{Pengaruh Corporate social responsibility Disclosure, Beta \\ Dan Price to book value (PBV) Terhadap Earnings response coefficient (ERC) \\ Pada Perusahaan Peraih ICSRA Tahun 2018}

Elkington, John. 1997. Cannibals with forks, the triple bottom line of twentieth century business. Gresik: Fascho.

Fariba, K., Hajiha, Z., Nabiyuni, S., \&Khalili, M. A. (2013). Effect of TheSocial Accountability on Incoming and Earnings Response Constant. Total quality Management, 1(1).

Financial Accounting Standards Board (FASB). 1984. Statement of Financial Accounting Concepts No.5: Recognition and Measurement in Financial Statement of Business Enterprises. Stamford. Connecticut.

Ghozali, Imam. 2016. Aplikasi Analisis Multivariete Dengan Program IBM SPSS 23. (Edisi 8). Cetakan ke VIII. Semarang: Badan Penerbit Universitas Diponegoro.

Harahap, Sofyan Syafri. 2015. Analisa Kritis atas Laporan Keuangan.Jakarta: PT Raja Grafindo Persada.

Horne, James C. Van dan John M Wachowicz, Jr. 2012. Prinsip-prinsip Manajemen Keuangan.(Edisi 13). Jakarta: Salemba Empat.

Ikatan Akuntan Indonesia. 2015. Pernyataan Standar Akuntansi Keuangan. Jakarta: Ikatan Akuntan Indonesia.

Imroatussolihah, E. (2013). "Pengaruh Risiko, Leverage, Peluang Pertumbuhan, Persistensi Laba dan Kualitas Tanggung Jawab Sosial Perusahaan terhadap Earning Response Coefficient pada Perusahaan High Profile". Jurnal IlmuManajemen (JIM), 1(1).

Indra, A. Z. dkk, 2011. "Analisis Faktor-faktor yang Mempengaruhi Earnings response coefficient (ERC) : Studi pada Perusahaan Properti dan Real Eastate yang Terdaftar di Bursa Efek Indonesia". Jurnal Akuntansi dan Keuangan. 16 (1): 1-22.

ISO. 2007 "ISO 26000: Guidance on Social Responsibility" dari http://www.pmhr.ir/unit/apo/pdf/iso26000/mod_2_iso _26000.pdf.

Jogiyanto. 2010. Teori Portofolio dan Analisis Investasi. Yogyakarta : BPFE.

Kasmir. (2014). Bank dan Lembaga Keuangan Lainnya. Edisi Revisi, Cetakan keempatbelas, PT. Raja Grafindo Persada, Jakarta.

Maith, Hendry A. 2013. "Analisis Laporan Keuangan Dalam Mengukur Kinerja Keuangan Pada PT. Hanjaya Mandala Sanpoerna Tbk". Jurnal EMBA 619 Volume 1 Nomor 3 Halaman 619-628. Fakultas Ekonomi dan Bisnis, Jurusan Akuntansi Universitas Sam Ratulangi, Manado.
Mulyani, Sri. Dkk, 2007. "Faktor-faktor yang Mempengaruhi Earnin Response Coefficient pada Perusahaan yang Terdaftar pada Bursa Efek Jakarta”. JAAI. 11 (1): 35-45.

Munawir. 2007. Analisis Laporan Keuangan. Yogyakarta : Edisi Empat, Liberty.

Murwaningsih, Etty. 2008. "Pengujian Simultan: Beberapa Faktor Yang mempengaruhi Earnings response coefficient (ERC)". Simposium Nasional Akuntansi XI. Pontianak.

Peraturan Pemerintah No. 47 tahun 2012 tentang Tanggung Jawab Sosial dan Lingkungan Perseroan Terbatas.

Prastowo, Joko \& Miftahul Huda. 2011. Corporate social responsibility, Kunci Meraih Kemuliaan Bisnis. Yogyakarta: Samudera Biru.

Rawi dan Muchlis, Munawar, 2010. "Kepemilikan Manajemen, Kepemilikan Instansi, Laverage dan Corporate Social Responsibily". Simposium Nasional Akuntansi XIII. Purwokerto.

Samsul, Mohammad. 2006. Pasar Modal dan Manajemen Portofolio. Surabaya : Erlangga.

Schipper, K., dan Vincent, L. 2003. "Earnings quality". Accounting horizons, 17, 97-110.

Scott, William R. 2009. Financial Accounting Theory. Toronto Canada: Prentice-Hall.

Silalahi, S. P. (2014). "Pengaruh Corporate Social Responsibility (CSR) Disclosure, Beta dan Price To Book Value (PBV) terhadap Earnings Response Coefficient (ERC) (Studi Empiris Pada Perusahaan Manufaktur Yang Terdaftar Di Bursa Efek Indonesia)". Jurnal Ekonomi, 22 (01), 61-74.

Sugiyono. 2010. Metode Penelitian Pendidikan Pendekatan Kuantitatif, kualitatif, dan R\&D. Bandung: Alfabeta.

Suwardjono. 2005. Teori Akuntansi Perekayasaan Pelaporan Keuangan. Yogyakarta: BPFE.

Tandelilin, Eduardus. (2001). Analisis Investasi dan manajemen Portofolio. Yogyakarta : BPFE.

Undang-undang Nomor 25 Tahun 2007 Tentang Penanaman Modal.

Undang-undang Republik Indonesia Nomor 40 tahun 2007 tentang Perseroan Terbatas.

Undan-undang Nomor 32 tahun 2009 tentang Perlindungan dan Pengelolaan Lingkungan Hidup. 
Wibisono, Yusuf. 2007. Membedah Konsep\&Aplikasi CSR. Gresik: Fascho Publishing.

Widiyanto, M.A. (2013). Statistika Terapan, Konsep dan Aplikasi SPSS/Lisrel dalam Penelitian Pendidikan, Psikologi dan Ilmu Sosial Lainya.Jakarta : PT Elex Media Komputindo.

World Business Council for Sustainable Development. 2000. Corporate social responsibility: Making Good Business Sense. World Business \& Economics Council for Sustainable Development: Ganeva

Wulandari, K. T., \& Wirajaya, I. (2014). "PengaruhPengungkapan Corporate Social Responsibility terhadap Earnings Response Coefficient". E-Jurnal Akuntansi Universitas Udayana, 6.3, 355-369. 